\section{Serum Concentrations of Interleukin 6 in the General Adult Population: Possible Implications for Anti-IL-6 Therapy in SARS-Cov-2 Infection and IL-6-Related Diseases}

Alende-Castro $\mathrm{V}^{1}$, Alonso-Sampedro $\mathrm{M}^{2}$, Gude $\mathrm{F}^{2}$, GonzalezQuintela $\mathrm{A}^{1}$

${ }^{1}$ Department of Internal Medicine, Complejo Hospitalario Universitario, Health Research Institute of Santiago de Compostela (IDIS), Santiago de Compostela, Spain

${ }^{2}$ Department of Clinical Epidemiology, Complejo Hospitalario Universitario, Health Research Institute of Santiago de Compostela (IDIS), Santiago de Compostela, Spain

J Investig Allergol Clin Immunol 2021; Vol. 31(1): 75-78 doi: 10.18176/jiaci.0601

Key words: IL-6. Age. Sex.

Palabras clave: IL-6. Edad. Género.

The cytokine interleukin (IL) 6 plays an important role in health and disease [1]. Serum IL-6 is a well-known inflammatory marker [2]. Moreover, IL-6-neutralizing therapies are used in a variety of inflammatory diseases, including rheumatoid arthritis, polyarticular and systemic juvenile idiopathic arthritis, giant cell arteritis, Castleman disease, and chimeric antigen receptor T-cell (CAR-T) therapy-induced cytokine release syndrome [3], as well as in some forms of severe asthma [4]. Interest in serum IL-6 concentrations has grown during the ongoing coronavirus (SARS-CoV-2) pandemic [5], because infection may be followed by severe, life-threatening immune responses that include greatly increased serum IL-6 concentrations [6-9]. Furthermore, serum IL-6 concentrations may have prognostic value [7] and may be used as a criterion for initiating anti-IL-6 therapy [9]. Tocilizumab is a humanized anti-IL-6 receptor monoclonal antibody that is being tested in patients with severe SARS-CoV-2 infection [8,9], because it was used with some success in analogous severe cytokine release syndrome after CAR-T therapy [3]. This study aimed to describe serum IL-6 concentrations in adults. Given the paucity of reports on the normal distribution of serum IL- 6 concentrations, studies in the general population may help to interpret abnormal values of laboratory determinations in disease.

This study is a part of a cross-sectional survey of a general adult population in northwest Spain, as described elsewhere $[10,11]$. Briefly, an age-stratified random sample from a single municipality was included in the A-Estrada Glycation and Inflammation Study (AEGIS), which was reviewed and approved by the Regional Ethics Committee (code 2010-315). A total of 1516 individuals (68\% of those who were eligible) agreed to participate, and 17 patients with active inflammatory disease were excluded. The median age of the 1499 remaining participants was 52 years (range, 18-91 years), and 669 (44.6\%) were men. Serum IL-6 was 
measured using immunochemiluminescence assay (Immulite 2000 System, Siemens Healthcare Diagnostics) immediately after blood sampling in all participants. According to the manufacturer's instructions, the analytical sensitivity of the assay is $2 \mathrm{pg} / \mathrm{mL}$, and the upper reference value in adults is $5.9 \mathrm{pg} / \mathrm{mL}$.

The Table shows serum IL-6 concentrations in relation to demographic factors (age and sex), lifestyle variables (alcohol consumption and smoking), body mass index, history of asthma, and atopy in the study population. Serum concentrations were undetectable $(<2 \mathrm{pg} / \mathrm{mL})$ in 736 individuals (49.1\%). Cases with undetectable concentrations were attributed an arbitrary value of $2 \mathrm{pg} / \mathrm{mL}$ for the statistical calculations. Serum IL-6 concentrations were higher than the upper reference value $(>5.9 \mathrm{pg} / \mathrm{mL})$ in 145 individuals (9.7\%). Moreover, they were higher than $40 \mathrm{pg} / \mathrm{mL}$ (a potential threshold for initiating anti-IL-6 therapy in some settings) in 12 individuals $(0.8 \%)$. Five of these 12 individuals were males. Their median age was 50 years (range, 20-79 years). A 34-yearold man with a baseline IL-6 concentration of $44.9 \mathrm{pg} / \mathrm{mL}$ developed Hodgkin lymphoma 2 years later. A 79-year-old man with a baseline IL- 6 concentration of $104.0 \mathrm{pg} / \mathrm{mL}$ developed rectal adenocarcinoma 2 years later. The clinical records of these 12 outliers and their 5-year follow-up were otherwise unremarkable. The median (IQR) serum IL-6 concentration in the study population was $2.1 \mathrm{pg} / \mathrm{mL}(<2-3.4 \mathrm{pg} / \mathrm{mL}$; range, $<2-107 \mathrm{pg} / \mathrm{mL}$ ). After excluding outliers with IL-6 $>40 \mathrm{pg} / \mathrm{mL}$, the median (IQR) values remained unchanged.

Table. Serum Concentrations of IL-6 in the Adult Population (Stratified by Demographic Factors, Lifestyle Factors, Body Mass Index, History of Asthma and Atopy) and Multivariate Analysis (Logistic Regression) of Covariates Associated With High IL-6 Concentrations (>4.0 pg/mL [Top Quintile])

\begin{tabular}{|c|c|c|c|c|c|c|}
\hline & \multirow[t]{2}{*}{ No. } & \multicolumn{3}{|c|}{ Univariate Analysis $^{\mathrm{a}}$} & \multicolumn{2}{|l|}{ Multivariate Analysis ${ }^{\mathrm{b}}$} \\
\hline & & $\begin{array}{c}\text { Median } \\
\text { (IQR range) }\end{array}$ & $\begin{array}{c}97.5 \text { th } \\
\text { percentile }\end{array}$ & $P$ Value & $\begin{array}{c}\text { OR } \\
(95 \% \mathrm{CI})\end{array}$ & $P$ Value \\
\hline \multicolumn{7}{|l|}{ Sex } \\
\hline Female & 830 & $<2(<2-3.2)$ & 14.3 & Ref. & 1 & Ref. \\
\hline Male & 669 & $2.4(<2-3.8)$ & 14.9 & $<.001$ & $1.58(1.14-1.20)$ & .006 \\
\hline \multicolumn{7}{|l|}{ Age, y } \\
\hline $18-40$ & 424 & $<2(<2-2.6)$ & 11.8 & Ref. & 1 & Ref. \\
\hline$>40-60$ & 528 & $2.1(<2-3.1)$ & 10.8 & $<.001$ & $1.21(0.80-1.85)$ & .353 \\
\hline$>60-80$ & 473 & $2.7(<2-4.5)$ & 21.8 & $<.001$ & $3.05(2.00-4.66)$ & $<.001$ \\
\hline$>80$ & 74 & $3.2(<2-5.1)$ & 24.5 & $<.001$ & $6.10(3.33-11.1)$ & $<.001$ \\
\hline \multicolumn{7}{|l|}{ Alcohol consumption, units/wk } \\
\hline Abstainers $(<1)$ & 539 & $2.2(<2-3.5)$ & 15.2 & Ref. & 1 & Ref. \\
\hline Light drinkers (1-13) & 591 & $<2(<2-3.3)$ & 12.6 & .038 & $0.78(0.56-1.08)$ & .140 \\
\hline Moderate drinkers (14-27) & 239 & $2.3(<2-3.6)$ & 14.4 & .362 & $0.61(0.39-0.93)$ & .024 \\
\hline Heavy drinkers $(>27)$ & 130 & $2.5(<2-4.4)$ & 24.1 & .087 & $0.92(0.55-1.52)$ & .747 \\
\hline \multicolumn{7}{|l|}{ Smoking } \\
\hline Never smokers & 820 & $<2(<2-3.4)$ & 13.7 & Ref. & 1 & Ref. \\
\hline Ex-smokers & 388 & $2.4(<2-3.7)$ & 18.0 & .008 & $1.20(0.85-1.70)$ & .297 \\
\hline Current smokers & 291 & $<2(<2-3.2)$ & 12.8 & .039 & $1.78(1.19-2.67)$ & .005 \\
\hline \multicolumn{7}{|l|}{ Body mass index, $\mathrm{kg} / \mathrm{m}^{2 \mathrm{~d}}$} \\
\hline Normal weight $(\leq 25)$ & 421 & $<2(<2-2.7)$ & 11.4 & Ref. & 1 & Ref. \\
\hline Overweight $(>25-30)$ & 567 & $2.2(<2-3.5)$ & 12.0 & $<.001$ & $1.37(0.93-2.01)$ & .107 \\
\hline Obese $(>30)$ & 511 & $2.4(<2-4.2)$ & 18.0 & $<.001$ & $1.89(1.28-2.78)$ & .001 \\
\hline \multicolumn{7}{|l|}{ History of asthma ${ }^{\mathrm{e}}$} \\
\hline No & 1342 & $2.2(<2-3.5)$ & 14.4 & Ref. & 1 & Ref. \\
\hline Yes & 120 & $<2(<2-3.0)$ & 14.7 & .149 & $0.97(0.57-1.65)$ & .920 \\
\hline \multicolumn{7}{|l|}{ Atopy (SPT positivity) } \\
\hline No & 1166 & $2.2(<2-3.6)$ & 14.7 & Ref. & 1 & Ref. \\
\hline Yes & 331 & $<2(<2-3.0)$ & 14.3 & $<.001$ & $0.83(0.57-1.20)$ & .328 \\
\hline
\end{tabular}

${ }^{a}$ Comparison with the reference category was performed using the Mann-Whitney test.

${ }^{b}$ Logistic regression. Dependent variable: high $(>4.0 \mathrm{pg} / \mathrm{mL}$, top quintile) serum IL-6 concentrations. All covariates were forced to enter the equation. Complete data were available for 1460 individuals.

'Alcohol consumption was calculated as the sum of units regularly consumed per week ( 1 glass of wine or 1 is approximately equivalent to $10 \mathrm{~g}$ of alcohol or 1 unit; 1 glass of spirits is approximately equivalent to $20 \mathrm{~g}$ of alcohol or 2 units).

dBody mass index was calculated as the weight (in $\mathrm{kg}$ ) divided by the square of the height (in meters).

ePositive answer to the question "Have you ever been diagnosed as having asthma?" (data were not available for 37 individuals).

${ }^{\mathrm{f}}$ At least 1 positive skin prick test result $(>3 \mathrm{~mm}$ ) to house dust mites (Dermatophagoides pteronyssinus and Lepidoglyphus destructor), pollens (Phleum pratense, Plantago lanceolata, Betula alba, and Parietaria judaica), vegetable pan-allergens (profilin and peach lipid transfer protein), molds (Alternaria alternata and Aspergillus species), and animal dander (dog and cat) (data were not available for 2 individuals). 
Serum IL-6 concentrations increased with age (Table). In individuals older than 60 years, the 97.5 th percentile was twice as high as that of individuals younger than 60 years (Table). In the multivariate analyses (logistic regression), age was the strongest factor associated with high IL-6 levels $(>4.0 \mathrm{pg} / \mathrm{mL}$, top quintile) (Table). Serum IL-6 concentrations were higher in males than in females, although the 97.5 th percentile was similar for both sexes (Table). Light-tomoderate alcohol consumption tended to be negatively associated with IL-6 concentrations (Table); this finding is consistent with an overall anti-inflammatory effect of alcohol consumption at these amounts [10]. Consistent with its proinflammatory effect, smoking tended to be associated with higher IL-6 concentrations after adjusting for covariates (Table) [10]. Overweight and, more particularly, obesity were associated with higher IL-6 concentrations (Table). Adipose tissue produces and releases a variety of proinflammatory mediators, including IL-6 [12]. Obesity has been found to be associated with higher IL- 6 concentrations in some patients with asthma [13]. In fact, the endotype of non-type 2 neutrophilic asthma is associated both with obesity and with high serum IL-6 concentrations [13-15]. Furthermore, an elevated serum IL-6 concentration in patients with adult-onset asthma is associated with a worse asthma outcome [15]. In our experience, a history of asthma (as defined by a positive response to the question "Have you ever been diagnosed as having asthma?") was not associated with IL-6 concentrations in the general population (Table). Atopy (as defined by positive skin prick test [SPT] results to a panel of common aeroallergens in the area) was associated with lower IL-6 concentrations, although this effect was largely attenuated after adjusting for age (Table). Among those with a history of asthma, IL-6 concentrations were higher in SPT-negative individuals $(\mathrm{n}=55)$ than in SPT-positive individuals $(\mathrm{n}=65)$ (median, $2.4 \mathrm{pg} / \mathrm{mL}[<2-3.7 \mathrm{pg} / \mathrm{mL}]$ vs $<2 \mathrm{pg} / \mathrm{mL}[<2-2.4 \mathrm{pg} / \mathrm{mL}$ ], respectively; $P=.013$ [MannWhitney test]), although that difference was also attenuated after adjusting for age (data not shown).

In summary, serum IL-6 concentrations vary widely in the general adult population. A small number of individuals with no apparent inflammatory disease have markedly abnormal serum IL-6 concentrations. Metabolic factors (obesity) and lifestyle factors (alcohol consumption and smoking) may affect serum IL-6 concentrations to some degree. Serum IL-6 concentrations are slightly higher in males than in females and increase significantly with age. The latter observation is particularly important for diseases that are either more frequent or clinically more severe in older patients, such as some systemic inflammatory diseases, some forms of asthma, and SARS-CoV-2-induced disease [3-5,15]. The significance of a specific high concentration of IL-6 may differ depending on the age group considered. These results may help to interpret the magnitude of increased IL- 6 levels in SARS-CoV-2 and IL-6-related inflammatory diseases.

\section{Funding}

The study was supported by grants (PI16/01404 and PI16/01395), the Spanish Network for Addictive Disorders (Red de Trastornos Adictivos, RD16/0017/0018), and the Spanish Network for Preventive Activity \& Health
Promotion Research in Primary Care (Red de Actividades Preventivas y de Promoción de Salud en Atención Primaria, RD16/0007/0006) of the Carlos III Institute of Health (Instituto de Salud Carlos III [ISCIII], Spanish Ministry of Health) and by FEDER funds.

\section{Conflicts of Interest}

The authors declare that they have no conflicts of interest.

\section{References}

1. Hunter CA, Jones SA. IL-6 as a keystone cytokine in health and disease. Nat Immunol. 2015;16:448-57.

2. Glady L, Lavaux T, Charchour R, Lacorte JM, Lessinger JM. Interleukin-6 chemiluminescent immunoassay on Lumipulse G600 II: analytical evaluation and comparison with three other laboratory analyzers. Clin Chem Lab Med. 2020;58:e229-31.

3. Rubbert-Roth A, Furst DE, Nebesky JM, Jin A, Berber E. A Review of recent advances using tocilizumab in the treatment of rheumatic diseases. Rheumatol Ther. 2018;5:21-42.

4. Esty B, Harb H, Bartnikas LM, Charbonnier LM, Massoud AH, Leon-Astudillo C, et al. Treatment of severe persistent asthma with IL-6 receptor blockade. J Allergy Clin Immunol Pract. 2019;7:1639-42.

5. Guan WJ, Ni ZY, Hu Y, Liang WH, Ou CQ, He JX, et al; China Medical Treatment Expert Group for Covid-19. Clinical characteristics of Coronavirus disease 2019 in China. N Engl J Med. 2020;382:1708-20

6. McGonagle D, Sharif K, O'Regan, Bridgewood C. The role of cytokines including interleukin-6 in COVID-19 induced pneumonia and macrophage activation syndrome-like disease. Autoimmun Rev. 2020;19:102537.

7. Henry BM, de Oliveira MHS, Benoit S, Plebani M, Lippi G. Hematologic, biochemical and immune biomarker abnormalities associated with severe illness and mortality in coronavirus disease 2019 (COVID-19): a meta-analysis. Clin Chem Lab Med. 2020;58:1021-8.

8. Buonaguro FM, Puzanov I, Ascierto PA. Anti-IL6R role in treatment of COVID-19-related ARDS. J Transl Med. 2020;18:165.

9. Fu B, Xu X, Wei H. Why tocilizumab could be an effective treatment for severe COVID-19? J TransI Med. 2020;18:164.

10. Alende-Castro V, Alonso-Sampedro M, Vazquez-Temprano $N$, Tuñez C, Rey D, García-Iglesias C, et al. Factors influencing erythrocyte sedimentation rate in adults: new evidence for an old test. Medicine (Baltimore). 2019;98:e16816.

11. Dieguez-Alvarez M, Carballo I, Alonso-Sampedro M, Sopeña B, Gude F, Gonzalez-Quintela A. Serum immunoglobulin-A (IgA) concentrations in a general adult population: association with demographics and prevalence of selective IgA deficiency. Clin Chem Lab Med. 2020;58:e109-12.

12. Fantuzzi G. Adipose tissue, adipokines, and inflammation. J Allergy Clin Immunol. 2005;115:911-20.

13. Li X, Hastie AT, Peters MC, Hawkins GA, Phipatanakul W, Li H, et al. Investigation of the relationship between IL- 6 and type 2 biomarkers in patients with severe asthma. J Allergy Clin Immunol. 2020;145:430-3. 
14. Kalchiem-Dekel O, Yao X, Levine SJ. Meeting the challenge of identifying new treatments for type 2-low neutrophilic asthma. Chest. 2020;157:26-33.

15. Ilmarinen P, Tuomisto LE, Niemelä O, Danielsson J, Haanpaa J, Kankaanranta T, et al. Comorbidities and elevated IL-6 associate with negative outcome in adult-onset asthma. Eur Respir J. 2016:48:1052-62.

Manuscript received May 18, 2020; accepted for publication June 5, 2020.

\section{A Gonzalez-Quintela} Department of Internal Medicine Hospital Clínico Universitario University of Santiago de Compostela 15706 Santiago de Compostela, Spain E-mail: arturo.gonzalez.quintela@sergas.es 